Biogeosciences Discuss., 8, 831-856, 2011

www.biogeosciences-discuss.net/8/831/2011/

doi:10.5194/bgd-8-831-2011

(C) Author(s) 2011. CC Attribution 3.0 License.

\title{
Stable carbon isotope as a proxy for the change of phytoplankton community structure in cascade reservoirs from Wujiang River, China
}

B. Wang ${ }^{1}$, C. Q. Liu ${ }^{1}$, X. Peng ${ }^{1,2}$, F. Wang ${ }^{3}$, and C. Chen ${ }^{4}$

${ }^{1}$ State Key Laboratory of Environmental Geochemistry, Institute of Geochemistry, Chinese Academy of Sciences, Guiyang 550002, China

${ }^{2}$ Graduate School of the Chinese Academy of Sciences, Beijing 100039, China

${ }^{3}$ Institute of Applied Radiation, School of Environmental and Chemical Engineering, Shanghai University, Shanghai 201800, China

${ }^{4}$ School of Life Sciences, Guizhou Normal University, Guiyang 550001, China

Received: 5 January 2011 - Accepted: 7 January 2011 - Published: 31 January 2011

Correspondence to: B. Wang (baoliwang@163.com)

Published by Copernicus Publications on behalf of the European Geosciences Union.

$\delta^{13} \mathrm{C}$ as a proxy of phytoplankton community structure change

B. Wang et al.

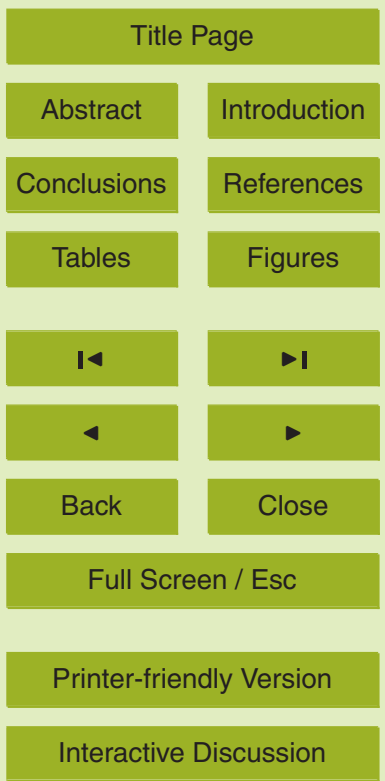




\section{Abstract}

Phytoplankton community structure and $\delta^{13} \mathrm{C}$ of dissolved inorganic carbon (DIC), particulate organic carbon (POC), and phytoplanktonic carbon (PPC), and the related hydro-chemical parameters have been seasonally investigated in the cascade reser5 voirs from the Wujiang River Basin. Average values of $\delta^{13} \mathrm{C}_{\mathrm{DIC}}, \delta^{13} \mathrm{C}_{\mathrm{POC}}$ and $\delta^{13} \mathrm{C}_{\mathrm{PPC}}$ were $-8.1 \pm 1.3 \%$ o, $-29.6 \pm 2.8 \%$ o, and $-30.9 \pm 4.5 \%$, respectively. Seasonal fluctuation of $\delta^{13} \mathrm{C}_{\mathrm{PPC}}$ was comparable to that of $\delta^{13} \mathrm{C}_{\mathrm{POC}}$ and larger than that of $\delta^{13} \mathrm{C}_{\mathrm{DIC}}$. The $\delta^{13} \mathrm{C}_{\mathrm{PPC}}$ values showed a significant linear correlation with $\delta^{13} \mathrm{C}_{\mathrm{POC}}$, indicating that endogenetic phytoplankton is the main source of POC in these cascade reservoirs. 10 Compared to environmental factors such as temperature, taxonomic differences are the main factor influencing $\delta^{13} \mathrm{C}_{\mathrm{PPC}}$ in this study. As a result, the contribution of Bacillariophyta to the total phytoplankton showed a significant negative correlation with $\delta^{13} \mathrm{C}_{\mathrm{PPC}}$ and $\Delta \delta^{13} \mathrm{C}\left(\delta^{13} \mathrm{C}_{\mathrm{PPC}}-\delta^{13} \mathrm{C}_{\mathrm{DIC}}\right)$, respectively, suggesting that $\delta^{13} \mathrm{C}_{\mathrm{PPC}}$ can be used to discern the change of phytoplankton community structure although only two kinds of dominant algae (i.e. Bacillariophyta and Chlorophyta) facilitate achieving this relationship. This relationship will have an important significance in understanding evolvement of phytoplankton community structure with time using geochemical technique once it is confirmed at a larger scale in field study.

\section{Introduction}

Natural carbon from different sources and experiencing different biogeochemical processes has different stable isotopic compositions. As for phytoplankton, stable carbon isotopic compositions are also dependent on fractionations that occur during photosynthesis and biosynthesis (O'Leary, 1981). Algal carbon fractionation is species-specific. The isotopic signal is significantly affected by biological factors such as cell size and
BGD

$8,831-856,2011$

\section{$\delta^{13} \mathrm{C}$ as a proxy of phytoplankton \\ community structure change}

B. Wang et al.

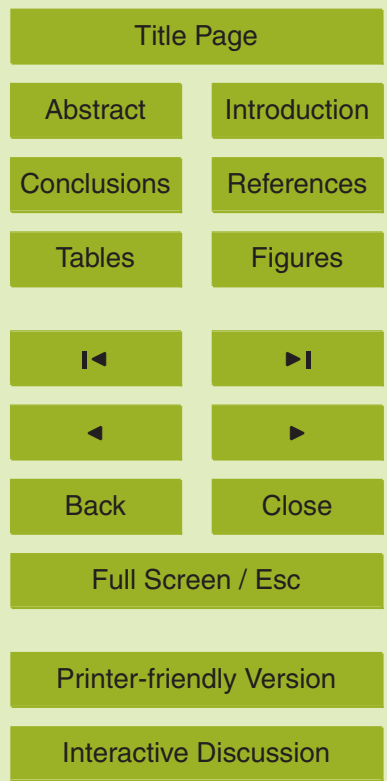


1985; Paneth and O'Leary, 1985; Popp et al., 1998; Keller and Morel, 1999; Riebesell et al., 2000). This species-specific characteristic provides the base on the potential possibility for carbon isotopic signal to discern the change of phytoplankton community structure.

5 However, environmental factors also significantly influence the algal carbon isotopic fractionation $\left(\varepsilon_{p}\right)$. Aqueous $\mathrm{CO}_{2}$ concentration exhibits a positive correlation to $\varepsilon_{p}$ in marine phytoplankton (Degens et al., 1968). Light climate strongly influences active transport of inorganic carbon into the cell and, in consequence, isotopic fractionation by the cell (Rost et al., 2002). Water velocity can also affect carbon isotopic signal of 10 the attached algae, possibly through effects on boundary layer thickness (Trudeau and Rasmussen, 2003). These studies complicate the interpretation of carbon isotopic data in geochemical and paleoceanographic applications (e.g., Rau et al., 1989; Freeman and Hayes, 1992) in the natural environment.

Although factors influencing algal $\varepsilon_{p}$ are variable and complex, carbon isotopic sig15 nal can be used as a powerful tool to understand biologically driven carbon cycle (e.g., Lehmann et al., 2004), especially when only a few factors are important and predictable. Here, we try to use carbon isotopic signal to discern the change of phytoplankton community. This approach is based on fundamental assumptions that influences on algal $\varepsilon_{\mathrm{p}}$ by environment factors are predictable and/or the extent of these influences are far less than that by biological factors in a given field, that is, algal $\varepsilon_{p}$ is mainly controlled by algal gene.

Damming river alters its hydrological condition, material cycle and then transforms aquatic ecosystem from riverine type to limnological type (Wetzel, 2001). Reservoirs created by dams show different trophic state due to different running time and geographical location along the impounded river. In natural situation, the upriver reservoir and the aged reservoir present higher trophic state owing to more nutrient load impounded than the downriver reservoir and younger reservoir (e.g., Humborg et al., 1997). However, because anthropogenic nutrient input might overcompensate the impounded effect of damming on the nutrient loads, downriver reservoir, sometimes,

BGD

$8,831-856,2011$

\section{$\delta^{13} \mathrm{C}$ as a proxy of phytoplankton \\ community structure change}

B. Wang et al.

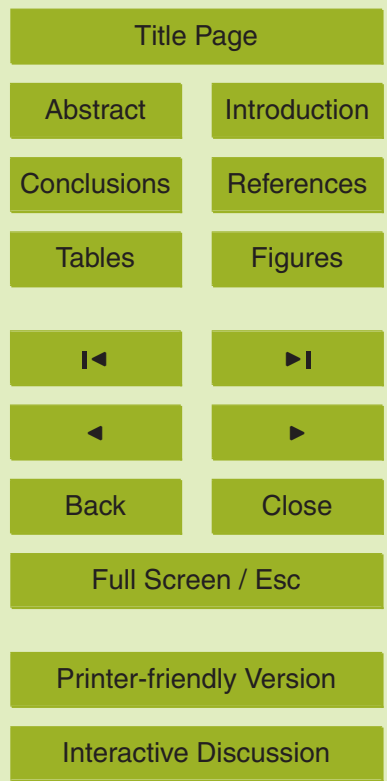


exhibits high trophic state (e.g., Wang et al., 2008). Accordingly, this will finally result in presence of different phytoplankton communities in the cascade reservoirs along the impounded river due to their different trophic state.

Wujiang River is a major hydropower source for China's massive west-to-east power 5 transmission project. A series of reservoirs were constructed along the Wujiang River and now it becomes a typical impounded river. We have seasonally investigated the phytoplankton community structure and determined the $\delta{ }^{13} \mathrm{C}$ values of dissolved inorganic carbon (DIC), particulate organic carbon (POC), and phytoplanktonic carbon (PPC), and related hydro-chemical parameters in the cascade reservoirs from the Wu10 jiang River Basin. The major aim of this study is to demonstrate if the $\delta^{13} \mathrm{C}$ values of PPC can be a proxy of the change of phytoplankton community structure and to better understand the carbon biogeochemical cycle in the cascade reservoirs. This study provides a linkage between phytoplankton ecology and stable carbon isotope geochemistry, and helps us develop prospective application for stable carbon isotope

\section{Material and methods}

\subsection{Study area and sampling}

The Wujiang River is a southern tributary of the Changjiang River, with a total length of $1037 \mathrm{~km}$ and a drainage area of $88267 \mathrm{~km}^{2}$. It has a runoff of 53.4 billion $\mathrm{m}^{3}$ with a fall of $2124 \mathrm{~m}$ and is the largest river in Guizhou Province. Investigations were carried out at eleven reservoirs and a total of 19 stations were selected (Fig. 1).

Water samples were collected at surface water (upper $0.5 \mathrm{~m}$ ) in July and October 2007 and in January and April 2008, which stand for summer, autumn, winter and spring, respectively. Water temperature, dissolved oxygen, and $\mathrm{pH}$ were measured in situ using a calibrated water quality probe (model YSI 6600). Samples for major cations and anions were filtered through $0.45 \mu \mathrm{m}$ filters. Samples for cation analysis

BGD

$8,831-856,2011$

\section{$\delta^{13} \mathrm{C}$ as a proxy of phytoplankton \\ community structure change}

B. Wang et al.

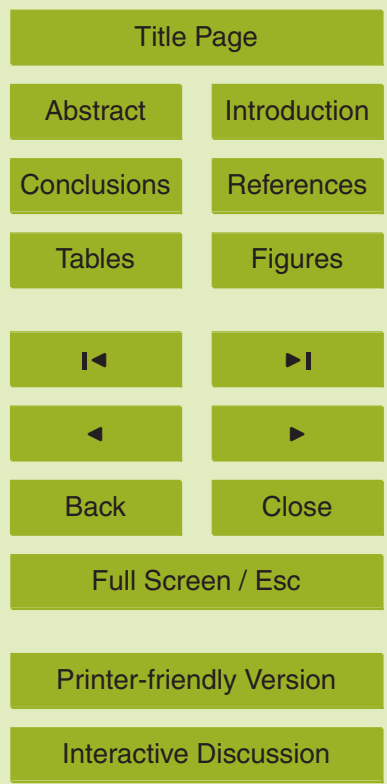


were acidified to $\mathrm{pH} 2$ with ultrapurified $\mathrm{HNO}_{3}^{-}$. Major cations $\left(\mathrm{Ca}^{2+}, \mathrm{Mg}^{2+}, \mathrm{K}^{+}\right.$, and $\mathrm{Na}^{+}$) were analyzed by atomic absorption spectrometry (AAS, PE51002, America) and the anions $\left(\mathrm{SO}_{4}^{2-}, \mathrm{NO}_{3}^{-}\right.$, and $\left.\mathrm{Cl}^{-}\right)$by high performance liquid chromatography (HP1100, SHIMADZU, Japan). $\mathrm{HCO}_{3}^{-}$was titrated with $\mathrm{HCl}$ on the spot. Samples for $\delta^{13} \mathrm{C}$ of dis5 solved inorganic carbon $\left(\delta^{13} \mathrm{C}_{\mathrm{DIC}}\right)$ measurement were collected by filtering $100 \mathrm{~mL}$ of water through $0.45 \mu \mathrm{m}$ filters with a syringe into polyethylene vials and then a saturated $\mathrm{HgCl}_{2}$ solution was injected into the vials to poison the samples. The vials were immediately closed without headspace with caps and sealed with seal film (Parafilm). Samples for $\delta^{13} \mathrm{C}$ of particulate organic carbon $\left(\delta^{13} \mathrm{C}_{\mathrm{POC}}\right)$ measurement were stored in high-density polyethylene bottles with screw closure $(1500 \mathrm{~mL}$, leak-poof). Bottles were rinsed three times prior to formal storage of water samples. Then they were filtered within $12 \mathrm{~h}$ with preburned $\left(500^{\circ} \mathrm{C}, 5 \mathrm{~h}\right) 47 \mathrm{~mm}$ Whatman GF/F glass fibre filter $(0.65 \mu \mathrm{m})$. In the laboratory, the samples were stored at $-20^{\circ} \mathrm{C}$ and freeze-dried before analysis. Samples for $\delta^{13} \mathrm{C}$ of phytoplankton $\left(\delta^{13} \mathrm{C}_{\mathrm{PPC}}\right)$ measurement were collected using a $64 \mu \mathrm{m}$ nylon mesh and immediately filtered with the same mesh on the spot, and then phytoplankton obtained were transported into vials and kept cool $\left(0-4{ }^{\circ} \mathrm{C}\right)$ in the field and were dried at $45^{\circ} \mathrm{C}$ in the laboratory within $24 \mathrm{~h}$.

\subsection{Quantitative and qualitative analysis of phytoplankton}

$1.5 \mathrm{~L}$ of surface water sample was preserved with Lugol's Solution for quantitative anal20 ysis of phytoplankton. Phytoplankton for qualitative analysis was collected by a $64 \mu \mathrm{m}$ nylon mesh and preserved with formaldehyde solution ( $2 \%$ final concentration). The precipitation method was used for taxon identification and counting (Zhang and Huang, 1991). Phytoplankton was quantitatively and qualitatively determined by a standard light microscope. The wet weight of phytoplankton was calculated according to its
BGD

$8,831-856,2011$

\section{$\delta^{13} \mathrm{C}$ as a proxy of phytoplankton \\ community structure change}

B. Wang et al.

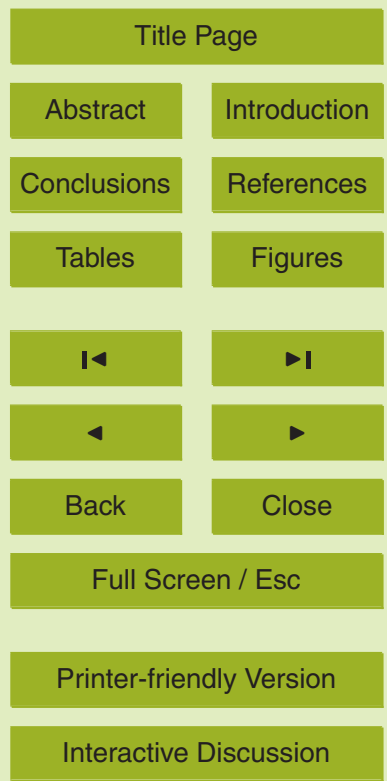




\subsection{Analysis of stable carbon isotope}

Water sample for $\delta^{13} \mathrm{C}_{\mathrm{DIC}}$ measurement was injected into the closed evacuated glass vessels containing the concentrated phosphoric acid and then heated at $50^{\circ} \mathrm{C}$ for $\mathrm{CO}_{2}$ extraction (Atekwana et al., 1998). Samples for $\delta^{13} \mathrm{C}_{\mathrm{POC}}$ and $\delta^{13} \mathrm{C}_{\mathrm{PPC}}$ measurements 5 were acidified with dilute hydrochloric acid and oven-dried overnight at $60^{\circ} \mathrm{C}$ just prior to carbon isotope determination. $\mathrm{PPC}$ and $\mathrm{POC}$ were transformed into $\mathrm{CO}_{2}$ using the high-temperature $\left(850^{\circ} \mathrm{C}, 5 \mathrm{~h}\right)$ sealed-quartz tube combustion method with copper oxide as oxidant (Buchanan and Corcoran, 1959) since the low-temperature $\left(550^{\circ} \mathrm{C}\right.$, $1 \mathrm{~h}$ ) combustion method could lead to large analytical uncertainty (Tao et al., 2001). ${ }_{10} \mathrm{CO}_{2}$ was cryogenically separated and its pressure and temperature were measured in a sensor (Edwards Barocel ${ }^{\circledR} 600$ ). The ${ }^{13} \mathrm{C} /{ }^{12} \mathrm{C}$ ratio of $\mathrm{CO}_{2}$ was determined on a dualinlet isotope ratio mass spectrometer (MAT 252). Carbon isotope data were reported and normalized following the " $\delta$ " denotation of Craig (1953) relative to the Vienna Pee Dee Belemnite (VPDB). The total precisions for concentration and $\delta^{13} \mathrm{C}$ analysis were 15 better than $3 \%(1 \sigma)$, and $0.1 \% \circ(1 \sigma)$, respectively.

Statistical analysis of the data was done with the software SPSS (version 11.5; SPSS Inc.). Pearson's correlation coefficient analysis was carried out.

\section{Results}

\subsection{Hydrogeochemical characteristics}

20 The study area has a subtropical monsoon humid climate. The average water temperature was $18.5^{\circ} \mathrm{C}$. The average dissolved oxygen (DO) and $\mathrm{pH}$ value were $8.6 \mathrm{mg} \mathrm{L}^{-1}$ and 8.2 , respectively (Table 1 ). The high $\mathrm{pH}$ value and $\mathrm{DO}$ are due to $\mathrm{CO}_{2}$ uptake and $\mathrm{O}_{2}$ release during algal photosynthesis. The Wujiang River Basin is underlain mainly by Permian and Triassic carbonate rocks. The river water chemistry is dominated by ${ }_{25} \mathrm{Ca}^{2+}, \mathrm{HCO}^{3-}, \mathrm{Mg}^{2+}$ and $\mathrm{SO}_{4}^{2-}$ (Table 1) and controlled by carbonate dissolution by

\section{BGD}

8, 831-856, 2011

\section{$\delta^{13} \mathrm{C}$ as a proxy of phytoplankton \\ community structure change}

B. Wang et al.

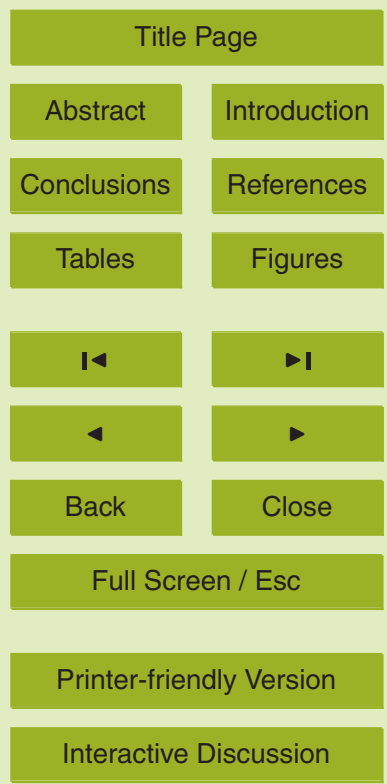


both carbonic and sulfuric acid (Liu, 2007). There are no significant differences in main hydro-chemical parameters of the investigated reservoirs among the main Wujiang River, the Sancha River, and the Maotiao River (Table 1).

\subsection{Phytoplankton community structure}

5 The seasonal variations of phytoplankton community and biomass were investigated (Table 2). Average biomass of phytoplankton (wet weight) was $13.90 \mathrm{mg} \mathrm{L}^{-1}$ in July 2007, 5.16 $\mathrm{mg} \mathrm{L}^{-1}$ in October 2007, $4.42 \mathrm{mg} \mathrm{L}^{-1}$ in January 2008 and $7.05 \mathrm{mg} \mathrm{L}^{-1}$ in April 2008, respectively. In eutrophic reservoirs Hongfeng and Baihua, the dominant algae were Cyanophyta and Chlorophyta. And in other reservoirs, they were Bacillar-

10 iophyta and Chlorophyta. Dinophyta was only largely observed in July 2007. Different reservoir showed different phytoplankton community structure, for example, the dominant algae in Hongfeng Reservoir were Chlorophyta and that in Wujiangdu Reservoir were Bacillariophyta in April 2008. Generally, phytoplankton in release water showed similar community structure to phytoplankton in surface water before dam from the same reservoir; however, the former had less biomass than the later, probably because release water came from the deep water of the reservoir and had lower temperature than surface water before dam (Wang et al., 2008).

\subsection{Carbon isotopic compositions}

Average values of $\delta^{13} \mathrm{C}_{\mathrm{DIC}}, \quad \delta^{13} \mathrm{C}_{\mathrm{POC}}$ and $\delta^{13} \mathrm{C}_{\mathrm{PPC}}$ were $-8.1 \pm 1.3 \%$ \% $(n=75)$, $20-29.6 \pm 2.8 \% \circ(n=74)$, and $-30.9 \pm 4.5 \%$ 。 $(n=63)$, respectively (Table 3$). \quad \delta^{13} \mathrm{C}$ values spanned a range from -3.3 to $-10.0 \%$ o for DIC, from -19.6 to $-34.5 \%$ o for POC, and from -15.1 to $-39.2 \%$ for PPC, respectively. Seasonal fluctuation of $\delta^{13} \mathrm{C}_{\mathrm{PPC}}$ was comparable to that of $\delta^{13} \mathrm{C}_{\mathrm{POC}}$ and larger than that of $\delta^{13} \mathrm{C}_{\mathrm{DIC}}$. For example, the average $\delta^{13} \mathrm{C}_{\mathrm{PPC}}$ values were $-25.7 \pm 3.3 \%$ in July 2007 and $-33.1 \pm 3.1 \%$ in January 2008 ; however, the average $\delta^{13} \mathrm{C}_{\mathrm{DIC}}$ values were $-7.8 \pm 1.5 \%$ o in July 2007 and $-8.6 \pm 0.7 \%$ in January 2008. During thermal stratification in water column (i.e. July 2007 and April
BGD

$8,831-856,2011$

\section{$\delta^{13} \mathrm{C}$ as a proxy of phytoplankton community structure change}

B. Wang et al.

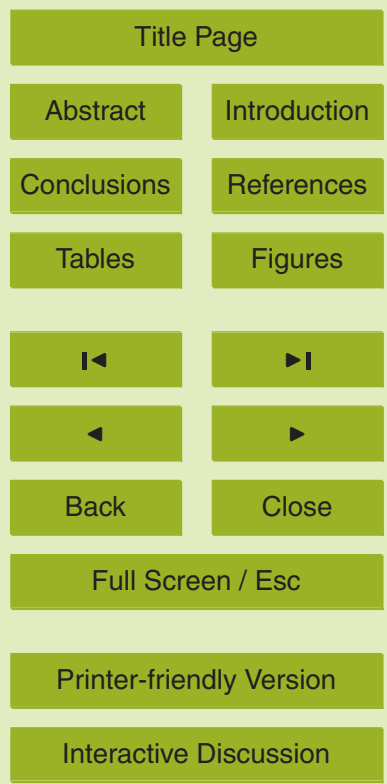


2008), $\delta^{13} \mathrm{C}_{\mathrm{DIC}}$ of release water showed more negative values than that of surface water before dam from the same reservoir (Table 3). The $\delta^{13} \mathrm{C}_{\mathrm{PPC}}$ values showed significant differences in the different reservoirs. For example, it was $-15.1 \%$ o in the Hongfeng Reservoir and $-31.7 \%$ o in the Wujiangdu Reservoir in April 2008, respec5 tively.

\section{Discussion}

\subsection{Carbon biogeochemical cycle in the reservoirs}

Understanding carbon biogeochemical cycle driven by phytoplankton is helpful to discover what are main factors controlling $\delta^{13} \mathrm{C}$ of phytoplankton. DIC and POC are the main carbon species in the reservoirs. $\mathrm{pH}$ values in these reservoir waters were generally larger than 8 , indicating a predominance of bicarbonate in $\mathrm{DIC}$. River $\mathrm{HCO}_{3}^{-}$is mainly derived from the carbonate weathering and $\mathrm{CO}_{2}$ originated from soil organic matter, and it theoretically has $\delta^{13} \mathrm{C}$ value of $-11.5 \%$ (Liu et al., 2008) since $\mathrm{CO}_{2}$ originated from the decomposition of soil organic matter is generally characterized by $\delta^{13} \mathrm{C}$ value of $-23 \%$ (Cerling et al., 1991). Contribution of $\mathrm{HCO}_{3}^{-}$from precipitation is ignorable because $\mathrm{pH}$ values of rain are generally lower than 5.6 in Guizhou province. The annual average partial pressure of $\mathrm{CO}_{2}$ in the reservoirs is higher than that of air (Lu et al., 2007; Yu et al., 2008a), suggesting the $\mathrm{CO}_{2}$ from atmosphere could also be ignored. Soil organic matter and aquatic phytoplankton are the possible contributors of riverine POC. $\delta^{13} \mathrm{C}_{\mathrm{PPC}}$ showed a perfect linear relationship with $\delta^{13} \mathrm{C}_{\mathrm{POC}}$ (Fig. 2), suggesting that $\mathrm{POC}$ was mainly derived from phytoplankton. With the development of reservoir after damming, riverine heterotrophic ecosystem is transformed to autotrophic one, and phytoplankton becomes the dominant contributor of POC.

Previous study indicated $\delta^{13} \mathrm{C}_{\mathrm{DIC}}$ in various reservoirs is significantly different from that in natural rivers, but is close to that in natural lakes (Yu et al., 2008b). The average $\delta^{13} \mathrm{C}_{\mathrm{DIC}}$ value was ca. $-8 \%$ o and larger than $-11.5 \%$ mentioned above because

\section{BGD}

8, 831-856, 2011

\section{$\delta^{13} \mathrm{C}$ as a proxy of phytoplankton \\ community structure change}

B. Wang et al.

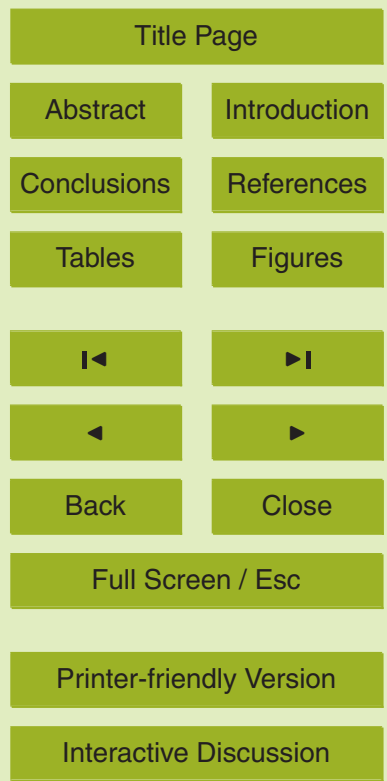


algal cells discriminate ${ }^{13} \mathrm{C}$ during photosynthetic $\mathrm{CO}_{2}$ fixation, which leaves the residual DIC pool enriched in ${ }^{13} \mathrm{C} . \mathrm{HCO}_{3}^{-}$concentrations decreased while the $\delta^{13} \mathrm{C}_{\mathrm{DIC}}$ and $\delta^{13} \mathrm{C}_{\mathrm{POC}}$ increased in the surface water of the reservoirs (Fig. 3). With the increase of phytoplanktonic biomass, algae assimilate more inorganic carbon and thereby exhibit 5 more positive $\delta{ }^{13} \mathrm{C}$ value (Fig. 3). So, photosynthesis is one of the main processes that affect $\delta^{13} \mathrm{C}_{\mathrm{DIC}}$ and $\delta^{13} \mathrm{C}_{\mathrm{POC}}$ in the surface water. Compared to the surface water before dam, DIC in release water showed the deficit in ${ }^{13} \mathrm{C}$ when thermal stratification developed in July 2007 and April 2008. Release water is from deep water of reservoir (Wang et al., 2008), and $\delta^{13} \mathrm{C}_{\mathrm{DIC}}$ values decrease with water depth (Yu et al., 2008b) as pho10 tosynthesis declines and respiration increase. Thus, respiration, which makes the DIC pool enriched in ${ }^{12} \mathrm{C}$, is the other main process affecting $\delta^{13} \mathrm{C}_{\mathrm{DIC}}$ in these reservoirs. Compared to DIC, POC (and PPC) showed larger fluctuations in $\delta{ }^{13} \mathrm{C}$ values (Table 3; Fig. 3) because phytoplankton had more influences on $\delta^{13} \mathrm{C}_{\mathrm{POC}}$ (and $\delta^{13} \mathrm{C}_{\mathrm{PPC}}$ ) than that on $\delta^{13} \mathrm{C}_{\mathrm{DIC}}$ during the transformation of inorganic carbon into organic carbon.

\subsection{Constraints on variations of the $\delta^{13} \mathrm{C}$ of phytoplankton}

The $\delta^{13} \mathrm{C}$ of assimilating inorganic carbon and carbon isotopic fractionation during photosynthetic carbon fixation control the $\delta^{13} \mathrm{C}$ of phytoplankton. Bicarbonate dominates DIC (Table 1). An equilibrium isotope effect in the hydration/dehydration reactions between bicarbonate and $\mathrm{CO}_{2}$ concentrates isotopically light carbon in the $\mathrm{CO}_{2}$ in a tem$0{ }^{\circ} \mathrm{C}$ and $8.4 \%$ lower at $30^{\circ} \mathrm{C}$ (Mook et al., 1974). The maximum carbon fractionation by all cellular carboxylation reactions has been suggested to lie in the range of 25.428.3\% (Goericke et al., 1994). In order to interpret our results, we adopted a value of $-10 \%$ and $-27 \%$, respectively, which represent the mid-point of the range in two sce25 narios mentioned above. Thus, the $\delta^{13} \mathrm{C}$ value of ca. $-18 \%$ is to be expected for $\mathrm{CO}_{2}$ involved photosynthetic carbon fixation if these $\mathrm{CO}_{2}$ are totally derived from the bicarbonate with $\delta^{13} \mathrm{C}$ average value of ca. $-8 \%$ (Table 3 ). And the most negative $\delta^{13} \mathrm{C}_{\mathrm{PPC}}$
BGD

8, 831-856, 2011

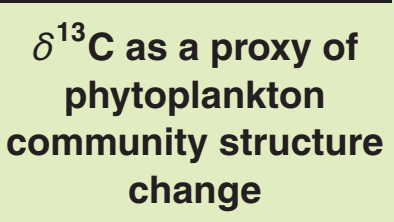

B. Wang et al.

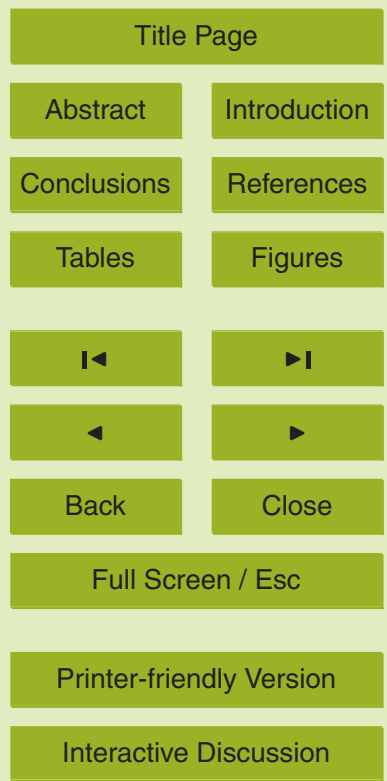

Interactive Discussion 
value of ca. $-45 \%$ is to be expected when diffusive $\mathrm{CO}_{2}$ uptake dominates inorganic carbon flux into cell with carboxylation fractionation of ca. $-27 \%$. However, it is hard to obtain the maximum fractionation in cellular carboxylation reactions in field study (e.g., Raven et al., 2002). In this study, the average value of $\delta^{13} \mathrm{C}_{\mathrm{PPC}}$ was $-30.9 \%$, about $568 \%$ of the most negative $\delta^{13} \mathrm{C}_{\mathrm{PPC}}$.

There are several factors influencing the $\delta^{13} \mathrm{C}_{\mathrm{PPC}}$. First is the inorganic carbon source. In this study, a significant negative correlation between the $\mathrm{HCO}_{3}^{-}$concentration and $\delta^{13} \mathrm{C}_{\mathrm{PPC}}$ was found $(R=-0.558, P<0.01)$. Obviously, $\mathrm{HCO}_{3}^{-}$as inorganic carbon source of phytoplankton can cause higher $\delta^{13} \mathrm{C}_{\mathrm{PPC}}$ values than $\mathrm{CO}_{2}$ does. Compared to $\mathrm{CO}_{2}$ uptake, the transport of $\mathrm{HCO}_{3}^{-}$through the plasmalemma alters the isotopic composition of the inorganic carbon pool inside the cell, which translates into a change in $\varepsilon_{\mathrm{p}}$. Second is temperature. Temperature can directly influence carboxylase activity and cellular metabolism ( $\mathrm{Li}$ et al., 1984) and thereby result in a change in $\varepsilon_{p}$. Increasing temperature can stimulate algal growth and thereby increase phytoplankonic biomass (e.g., Wang et al., 2008) and decrease the concentration of $\mathrm{HCO}_{3}^{-}$, and thus causes more positive $\delta^{13} \mathrm{C}_{\mathrm{PPC}}$ values. Third are biological factors such as taxonomic differences. Different algal taxa possess different carbon metabolism and growth rate, and will have much more influence on carbon isotopic fractionation in phytoplankton (e.g., Burkhardt et al., 1999). We will thoroughly discuss the effect of 20 taxonomic differences in the below.

\subsection{Effect of taxonomic differences on carbon isotopic fractionation}

The dominant phyla were Bacillariophyta and Chlorophyta in the investigated reservoirs (Fig. 4), thus the variation on the contribution of Bacillariophyta to the total phytoplankton (CBTP) was used to indicate the change of phytoplankton community structure. 25 The ratio of Chlorophyta to Bacillariophyta (CTB) was also calculated. The CBTP showed a significant correlation to the $\delta^{13} \mathrm{C}_{\mathrm{PPC}}$ and $\Delta \delta^{13} \mathrm{C}\left(\delta^{13} \mathrm{C}_{\mathrm{PPC}}-\delta^{13} \mathrm{C}_{\mathrm{DIC}}\right)$, respectively (Fig. 5), so did CTB ( $R=0.613$ and $0.496, P<0.01$, respectively), indicating

\section{BGD}

$8,831-856,2011$

\section{$\delta^{13} \mathrm{C}$ as a proxy of phytoplankton community structure change}

B. Wang et al.

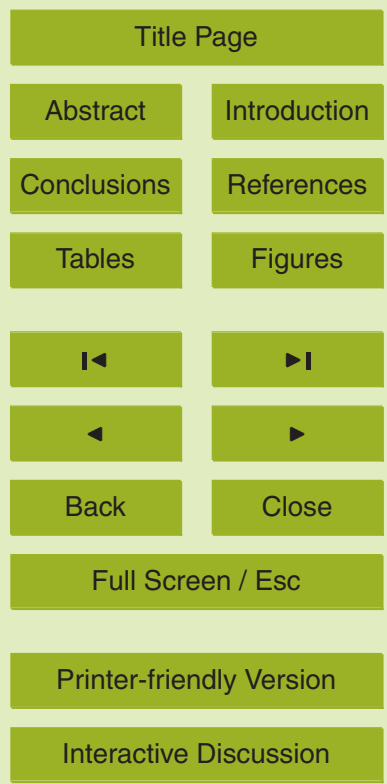


different phytoplankton community with different $\delta^{13} \mathrm{C}_{\mathrm{PPC}}$ and $\varepsilon_{p}$. This phenomenon is caused by reason that the mechanism of inorganic carbon acquisition and subsequent carbon isotopic fractionation during photosynthetic $\mathrm{CO}_{2}$-fixation are species-specific.

Phytoplankton obtains inorganic carbon either by passive diffusion of $\mathrm{CO}_{2}$ or active 5 uptake of $\mathrm{CO}_{2}$ and/or $\mathrm{HCO}_{3}^{-}$. Active $\mathrm{HCO}_{3}^{-}$entry is relative to algal $\mathrm{CO}_{2}$ concentrating mechanism (CCM), which is different among the phytoplankton taxa (Moroney and Ynalvez, 2007; Raven et al., 2008). Phytoplankton can use $\mathrm{HCO}_{3}^{-}$either by direct uptake or by extracellular conversion to $\mathrm{CO}_{2}$ by carbonic anhydrase (CA). Although the isotope fractionation associated with the conversion by $\mathrm{CA}$ would eliminate the isotopic difference between $\mathrm{HCO}_{3}^{-}$and $\mathrm{CO}_{2}$ and make the two carbon sources isotopically indistinguishable (Riebesell and Wolf-Gladrow, 1995), the change in activity of CA has an obvious influence on the net $\mathrm{CO}_{2}$ assimilation rate and thereby affects carbon isotope discrimination (Cousins et al., 2006).

Diatoms possess $\mathrm{C}_{4}$-like pathway whereby $\mathrm{C}_{4}$ compound such as malate and ox15 aloacetate (OAA) is decarboxylated to deliver $\mathrm{CO}_{2}$ to Rubisco (Reinfelder et al., 2004). After delivery of $\mathrm{HCO}_{3}^{-}$by specific transporter into cell, $\mathrm{HCO}_{3}^{-}$is either fixed into $\mathrm{C} 4$ compound by beta-carboxylase activity or conversion to $\mathrm{CO}_{2}$ through CA activity (Kroth et al., 2008). Beta-carboxylase activity appears related to strictly anaplerotic processes and reduces $\varepsilon_{p}$ associated with carbon fixation by no more than 2\%。 (Hayes, 2001; Cassar and Laws, 2007). This CCM provides sufficient $\mathrm{CO}_{2}$ for Rubisco in diatom. Extensive diatom blooms that occur in high nutrient low chlorophyll regions of the oceans (Gervais et al., 2002) suggest that diatoms are not $\mathrm{CO}_{2}$ limited under natural oceanic conditions. Obviously, larger $\varepsilon_{p}$ in $\mathrm{CO}_{2}$ fixation by Rubisco will be obtained under enough supply of $\mathrm{CO}_{2}$ (Fry, 1996), thus results lower $\delta^{13} \mathrm{C}$ of diatoms.

Compared with diatoms, green algae had higher $\delta^{13} \mathrm{C}$ in this study. CA plays an important role in CCM of green algae (Moroney and Ynalvez, 2007). External CA may significantly accelerate the rate of $\mathrm{CO}_{2}$ supply to the cell surface, and its activity can be induced by low- $\mathrm{CO}_{2}$ condition (Dionisio-Sese et al., 1990). Previous study demonstrated that external CA activity had a significant positive correlation with the
BGD

8, 831-856, 2011

\section{$\delta^{13} \mathrm{C}$ as a proxy of phytoplankton \\ community structure change}

B. Wang et al.

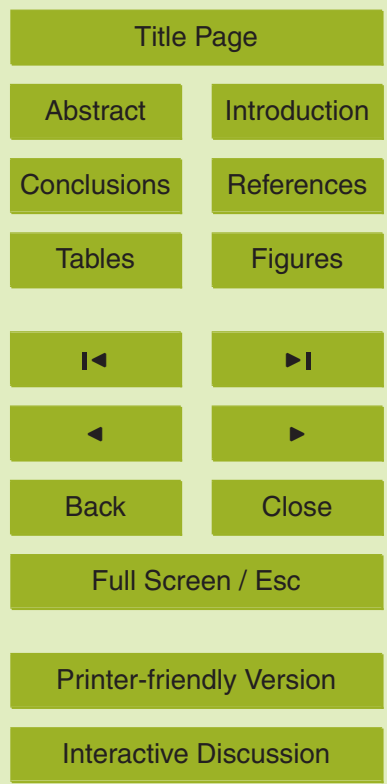


density of Chlorophyta in reservoirs Hongfeng and Baihua, and this phenomenon was not found for Bacillariophyta because of little proportion of Bacillariophyta with external $\mathrm{CA}$ (Wu et al., 2008). This means that, compared to diatoms, $\mathrm{CO}_{2}$ supply of green algae is not enough for photosynthetic carbon fixation by Rubisco, and smaller $\varepsilon_{p}$ under 5 this circumstance will be obtained for Chlorophyta. Cyanobacteria have a sophisticated CCM that, to some degree, is similar to green algae (Moroney and Ynalvez, 2007). It was also found that the activity of external CA showed close relation to the density of Cyanophyta in Aha reservoir (Wu et al., 2008). Cyanophyta possess Rubisco II for which the maximum carbon isotopic fractionation is $22 \%$, lower $8 \%$ o than $\varepsilon_{p}$ via

10 Rubisco I that belongs to green algae and diatoms (Hayes, 2001). So, Chlorophyta and Cyanophyta should exhibit higher $\delta^{13} \mathrm{C}$ than Bacillariophyta.

\section{$4.4 \quad \delta^{13} \mathrm{C}_{\mathrm{PPC}}$ versus the change of phytoplankton community structure}

Whether or not $\delta^{13} \mathrm{C}_{\mathrm{PPC}}$ can be used as a proxy of the change of phytoplankton community depends on what extent it is caused to change by algal species differences. In 5 the Fig. 5, we can find the fluctuations of $\delta^{13} \mathrm{C}$ values along the both sides of regression line, indicating that, besides taxonomic differences, other factors such as temperature and bicarbonate also have some influences on $\delta{ }^{13} \mathrm{C}_{\mathrm{PPC}}$ and $\Delta \delta^{13} \mathrm{C}$. We chose the data in April 2008, which had relative smaller temperature variations compared to the whole year, calculated and found a significant correlation between $\delta^{13} \mathrm{C}_{\mathrm{PPC}}$ and CBTP $(R=-0.61 ; P<0.01)$, indicating the more effect of taxonomic differences than that of temperature on $\delta^{13} \mathrm{C}_{\mathrm{PPC}}$. We also calculated the data when phytoplankton were predominated by Chlorophyta (CBTP $<10 \%$ ) and by Bacillariophyta (CBTP $>90 \%)$, respectively. These results demonstrated only biomass variation may be the other main factor affecting $\delta^{13} \mathrm{C}_{\mathrm{PPC}}$ when Chlorophyta predominate phytoplankton, and variations of bi25 carbonate and temperature had no significant influences on $\delta^{13} \mathrm{C}_{\mathrm{PPC}}$ (Fig. 6). Thus, taxonomic differences were the main factor influencing $\delta^{13} \mathrm{C}_{\mathrm{PPC}}$ in this study and both showed synchronous variations. $\Delta \delta^{13} \mathrm{C}$ exhibited similar variation to $\delta^{13} \mathrm{C}_{\mathrm{PPC}}$ because
BGD

8, 831-856, 2011

\section{$\delta^{13} \mathrm{C}$ as a proxy of phytoplankton \\ community structure change}

B. Wang et al.

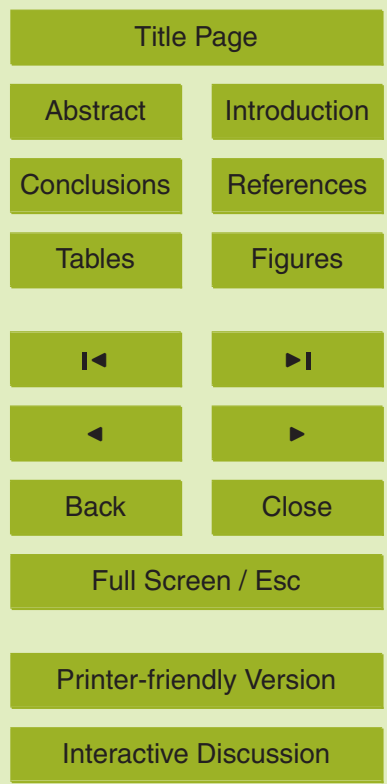


$\delta^{13} \mathrm{C}_{\mathrm{PPC}}$ had much larger fluctuation than $\delta^{13} \mathrm{C}_{\mathrm{DIC}}$ did here. It is expected that $\Delta \delta^{13} \mathrm{C}$ should show better relationship with algal species difference than $\delta^{13} \mathrm{C}_{\mathrm{PPC}}$ does in other field study at larger scale.

Factors influencing $\delta^{13} \mathrm{C}_{\mathrm{PPC}}$ are complex. We simplify these factors into two sorts: 5 environmental factors (e.g. temperature, nutrients, and light) and biological factors (e.g. carboxylase activity and CCM). Experimental studies have demonstrated influences on $\varepsilon_{p}$ by environmental factors are comparable to that by biological factors (e.g., Burkhardt et al., 1999; Rost et al., 2002). However, Raven et al. (2002) compiled substantial data about $\delta^{13} \mathrm{C}$ of organic matter in marine macroalgae and seagrasses collected from the natural environment and found the $\delta^{13} \mathrm{C}$ value correlates primarily with taxonomy and secondarily with ecology. This result was not consistent with the experimental studies, probably because experimental conditions could be controlled and influence of environmental factors on $\delta^{13} \mathrm{C}_{\mathrm{PPC}}$ therefore might be artificially expanded.

What's more, environmental factors, to a great extent, indirectly affect $\delta^{13} \mathrm{C}$ of phy15 toplankton via working on biological factors such as cellular metabolism and physiochemical function. Biological factors involve inorganic carbon acquisition and fixation and directly influence $\varepsilon_{p}$. As a result of the evolution of algae best adapted to the environment, existent algae that dominate in the aquatic environment are not fortuitous. From this point of view, $\delta^{13} \mathrm{C}$ and/or $\varepsilon_{p}$ of phytoplankton can reflect the change of phytoplankton community structure. In this study, we have demonstrated tight relationship between the $\delta^{13} \mathrm{C}_{\mathrm{PPC}}$ and phytoplankton community structure although only two kinds of dominant algae (i.e. Bacillariophyta and Chlorophyta) in the investigated reservoirs facilitate achieving this relationship. Extensive studies in experiment and field are needed to testify this relationship in the future. Once this relationship is confirmed at a larger scale, it will have an important significance in understanding evolvement of phytoplankton community structure with time using geochemical technique.

\section{BGD}

8, 831-856, 2011

\section{$\delta^{13} \mathrm{C}$ as a proxy of phytoplankton \\ community structure change}

B. Wang et al.

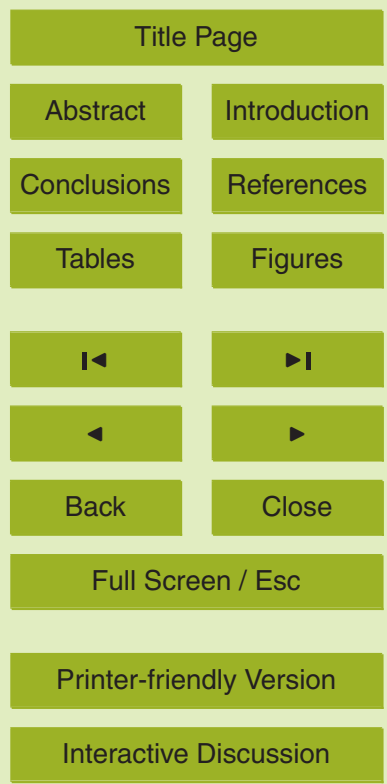


Acknowledgements. We are grateful to X. Liu and A. Dang for assistance in sample collection in the field and experimental work in laboratory; G. Li and N. An for assistance with carbon isotope analyses. This study was financially supported by the Foundation of Chinese Academy of Sciences (Grant No: kzcx2-yw-137) and by National Natural Science Foundation of China 5 (Grant Nos. 40721002 and 90610037).

\section{References}

Atekwana, E. A. and Krishnamurthy, R. V.: Seasonal variations of dissolved inorganic carbon and $\delta^{13} \mathrm{C}$ of surface water: application of a modified gas evolution technique, J. Hydrol., 205, 265-278, 1998.

Buchanan, D. L. and Corcoran, B. J.: Sealed tube combustions for the determination of carbon14 and total carbon, Anal. Chem., 31, 1635-1638, 1959.

Burkhardt, S., Riebesell, U., and Zondervan, I.: Effect of growth rate, $\mathrm{CO}_{2}$ concentration, and cell size on the stable carbon isotope fractionation in marine phytoplankton, Geochim. Cosmochim. Ac., 63, 3729-3741, 1999.

15 Cassar, N. and Laws, E. A.: Potential contribution of $\beta$-carboxylases to photosynthetic carbon isotope fractionation in a marine diatom, Phycologia, 46, 307-314, 2007.

Cerling, T. E., Solomon, D. K., Quade, J., and Bowman, J. R.: On the isotopic composition of carbon in soil carbondioxide, Geochim. Cosmochim. Ac., 55, 3403-3405, 1991.

Cousins, A. B., Badger, M. R., and von Caemmerer, S.: Carbonic anhydrase and its influence on carbon isotope discrimination during $\mathrm{C}_{4}$ photosynthesis, Insights from Antisense RNA in Flaveria bidentis, Plant Physiol., 41, 232-242, 2006.

Craig, H.: The geochemistry of stable carbon isotopes, Geochim. Cosmochim. Ac., 3, 53-92, 1953.

Degens, E. T., Guillard, R. R. L., Sackett, W. M., and Hellebust, J. A.: Metabolic fractionation of carbon isotopes in marine plankton - I. Temperature and respiration experiments, Deep-Sea Res., 15, 1-9, 1968.

Descolas-Gros, C. and Fontugne, M. R.: Carbon fixation in marine phytoplankton: carboxylase activities and stable carbon-isotope ratios; physiological and paleoclimatological aspects, Mar. Biol., 87, 1-6, 1985.

\section{BGD}

$8,831-856,2011$

\section{$\delta^{13} \mathrm{C}$ as a proxy of phytoplankton \\ community structure change}

B. Wang et al.

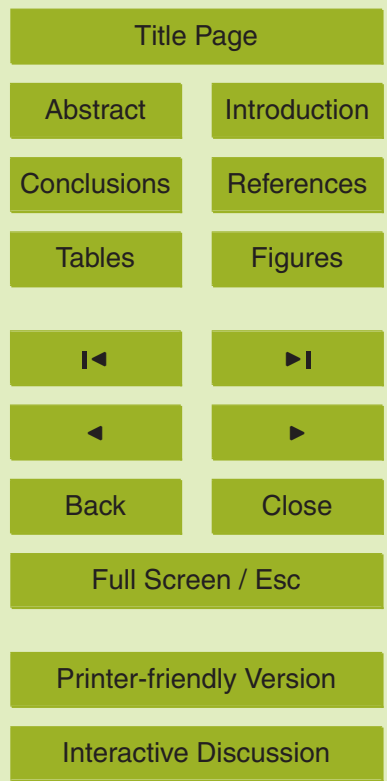


Dionisio-Sese, M. L., Fukuzawa, H., and Miyachi, S.: Light-induced carbonic anhydrase expression in Chlamydomonas reinhardtii, Plant Physiol., 94, 1103-1110, 1990.

Freeman, K. H. and Hayes, J. M.: Fractionation of carbon isotopes by phytoplankton and estimates of ancient $\mathrm{CO}_{2}$ levels, Global Biogeochem. Cy., 6, 185-198, 1992.

5 Fry, B.: ${ }^{13} \mathrm{C} /{ }^{12} \mathrm{C}$ fractionation by marine diatoms, Mar. Ecol.-Prog. Ser., 134, 283-294, 1996.

Gervais, F., Riebesell, U., and Gorbunov, M. Y.: Changes in primary productivity and chlorophyll a in response to iron fertilization in the Southern Polar frontal zone, Limnol. Oceanogr., 47, 1324-1335, 2002.

Goericke, R., Montoya, J. P., and Fry, B.: Physiology of isotopic fractionation in algae and cyanobacteria, in: Stable Isotopes in Ecology and Environmental Science, edited by: Lajhta, K. and Michener, R. H., Blackwell Science Publishers, Cambridge, MA, 187-221, 1994.

Hayes, J. M.: Fractionation of carbon and hydrogen isotopes in biosynthetic processes, Rev. Mineral. Geochem., 43, 225-277, 2001.

Humborg, C., Ittekkot, V., Cociasu, A., and Bodungen, B. V.: Effect of Danube River dam on Black Sea biogeochemistry and ecosystem structure, Nature, 386, 385-388, 1997.

Keller, K. and Morel, F. M. M.: A model of carbon isotopic fractionation and active carbon uptake in phytoplankton, Mar. Ecol.-Prog. Ser., 182, 295-298, 1999.

Kroth, P. G., Chiovitti, A., Gruber, A., Martin-Jezequel, V., Mock, T., Parker, M. S., Stanley, M. S., Kaplan, A., Caron, L., Weber, T., Maheswari, U., Armbrust, E. V., and Bowler, C.: A model for carbohydrate metabolism in the diatom Phaeodactylum tricornutum deduced from comparative whole genome analysis, PLoS ONE, 3, e1426, doi:10.1371/journal.pone.0001426, 2008.

Lehmann, M. F., Bernasconi, S. M., McKenzie, J. A., Barbieri, A., Simona, M., and Veronesi, M.: Seasonal variation of the $\delta^{13} \mathrm{C}$ and $\delta^{15} \mathrm{~N}$ of particulate and dissolved carbon and nitrogen in Lake Lugano: constraints on biogeochemical cycling in a eutrophic lake, Limnol. Oceanogr., 49, 415-429, 2004.

Li, K. W., Smith, J. C., and Platt, T.: Temperature response of photosynthetic capacity and carboxylase activity in Arctic marine phytoplankton, Mar. Ecol.-Prog. Ser., 17, 237-243, 1984.

Liu, C. Q.: Earth surface biogeochemical processes and mass cycles: karstic catchment ero30 sions and bioelements cycles in Southwest China, Science Press, Beijing, 2007 (in Chinese).

Liu, C. Q., Jiang, Y., Tao, F., Lang, Y., and Li, S.: Chemical weathering of carbonate rocks by sulfuric acid and carbon cycling in Southwest China, Geochimica, 37, 404-414, 2008 (in

\section{BGD}

8, 831-856, 2011

\section{$\delta^{13} \mathrm{C}$ as a proxy of phytoplankton \\ community structure change}

B. Wang et al.

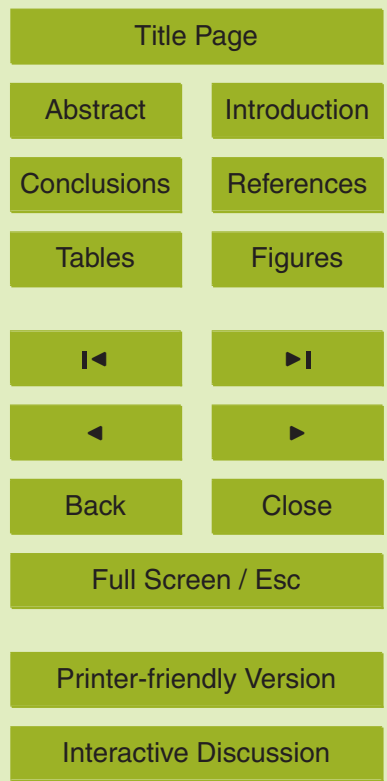


Chinese).

Lu, Y., Liu, C. Q., Wang, S., Xu, G., and Liu, F.: Seasonal variability of $p\left(\mathrm{CO}_{2}\right)$ in the two karst reservoirs, Hongfeng and Baihua Lakes in Guizhou Province, China, Env. Sci., 28, 26762681, 2007 (in Chinese).

5 Mook, W. G., Bommerson, J. C., and Staverman, W. H.: Carbon isotope fractionation between dissolved bicarbonate and gaseous carbon dioxide, Earth Planet. Sc. Lett., 22, 169-176, 1974.

Moroney, J. V. and Ynalvez, R. A.: A proposed carbon dioxide concentration mechanism in Chlamydomonas reinhardtii, Eukaryot. Cell, 6, 1251-1259, 2007.

10 O'Leary, M. H.: Carbon isotope fractionation in plants, Phytochemistry, 20, 553-567, 1981.

Paneth, P. and O'Leary, M. H.: Carbon isotope effect on dehydration of bicarbonate ion catalyzed by carbonic anhydrase, Biochemistry, 24, 5143-5147, 1985.

Popp, B. N., Laws, E. A., Bidigare, R. R., Dore, J. E., Hanson, K. L., and Wakeham, S. G.: Effect of phytoplankton cell geometry on carbon isotopic fractionation, Geochim. Cosmochim. Ac.,

$15 \quad 62,69-77,1998$.

Rau, G. H., Takahashi, T., and Marais, D. J. D.: Latitudinal variations in plankton $\delta^{13} \mathrm{C}$ : implications for $\mathrm{CO}_{2}$ and productivity in past oceans, Nature, 341, 516-518, 1989.

Raven, J. A., Johnston, A. M., Kubler, J. E., Korb, R., Mcinroy, S. G., Handley, L. L., Scrimgeour, C. M., Walker, D. I., Beardall, J., Vanderklift, M., Fredriksen, S., and Dunton, K. H.: Mechanistic interpretation of carbon isotope discrimination by marine macroalgae and seagrasses, Funct. Plant Biol., 29, 355-378, 2002.

Raven, J. A., Cockell, C. S., and De La Rocha, C. L.: The evolution of inorganic carbon concentrating mechanisms in photosynthesis, Philos. T. Roy. Soc. B, 363, 2641-2650, 2008.

Reinfelder, J. R., Milligan, A. J., and Morel, F. M. M.: The role of the $\mathrm{C}_{4}$ pathway in carbon accumulation and fixation in a marine diatom, Plant Physiol., 135, 2106-2111, 2004.

Riebesell, U. and Wolf-Gladrow, D.: Growth limits on phytoplankton, Nature, 373, 28, 1995.

Riebesell, U., Revill, A. T., Holdsworth, D. G., and Volkman, J. K.: The effects of varying $\mathrm{CO}_{2}$ concentration on lipid composition and carbon isotope fractionation in Emiliania huxleyi, Geochim. Cosmochim. Ac., 64, 4179-4192, 2000.

30 Rost, B., Zondervan, I., and Riebesell, U.: Light-dependent carbon isotope fractionation in the coccolithophorid Emiliania huxleyi, Limnol. Oceanogr., 47, 120-128, 2002.

Trudeau, V. and Rasmussen, J. B.: The effect of water velocity on stable carbon and nitrogen isotope signatures of periphyton, Limnol. Oceanogr., 48, 2194-2199, 2003.

BGD

$8,831-856,2011$

\section{$\delta^{13} \mathrm{C}$ as a proxy of phytoplankton \\ community structure change}

B. Wang et al.

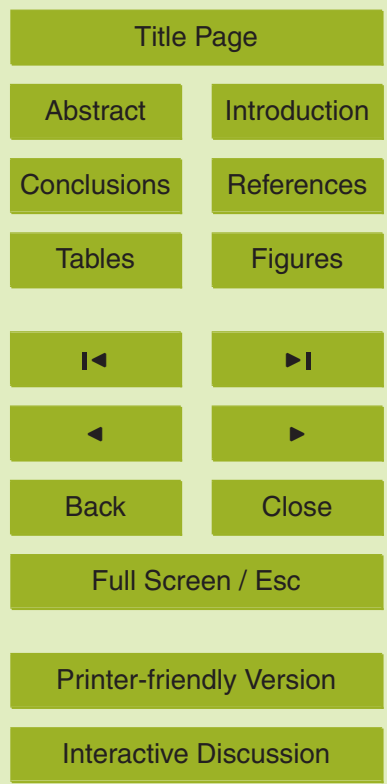


Tao, F. X., Aucour, A. M., Sheppard, S. M. F., Liu, C. Q., Leng, X. T., Wang, S. L., Liu, G. S., and $\mathrm{Xu}, \mathrm{W} . \mathrm{B}$.: Evaluation of the sealed-tube low temperature combustion method for the ${ }^{13} \mathrm{C} /{ }^{12} \mathrm{C}$ and ${ }^{2} \mathrm{H} /{ }^{1} \mathrm{H}$ ratio determinations of cellulose nitrate, Chin. J. Chem., 19, 1089-1096, 2001.

Wang, B., Liu, C. Q., Wang, F., Yu, Y., and Zhang, L.: The distributions of autumn picoplankton in relation to environmental factors in the reservoirs along the Wujiang River in Guizhou Province, SW China, Hydrobiologia, 598, 35-45, 2008.

Wetzel, R. G.: Limnology: Lake and River Ecosystems, 3rd edn., Academic Press, San Diego, CA, 2001.

Wu, Y., Li, P., Wang, B., Liu, C. Q., He, M., and Chen, C.: Composition and activity of external carbonic anhydrase of microalgae from Karst Lakes in China, Phycol. Res., 56, 76-82, 2008.

Yu, Y., Liu, C. Q., Wang, F., Wang, B., Wang, S., and Liu, F.: Spatiotemporal characteristics and diffusion flux of partial pressure of dissolved carbon dioxide $\left(p \mathrm{CO}_{2}\right)$ in Hongjiadu reservoir, Chin. J. Ecol., 27, 1193-1199, 2008a (in Chinese).

Yu, Y., Liu, C. Q., Wang, F., Wang, B., Li, J., and Li, S.: Dissolved inorganic carbon and its isotopic differentiation in cascade reservoirs in the Wujiang drainage basin, Chinese Sci. Bull., 53, 3371-3378, 2008b.

Zhang, Z. S. and Huang, X. F.: Study methods for the freshwater plankton, Scientific Press, Beijing, 1991 (in Chinese).

\section{BGD}

8, 831-856, 2011

\section{$\delta^{13} \mathrm{C}$ as a proxy of phytoplankton \\ community structure change}

B. Wang et al.

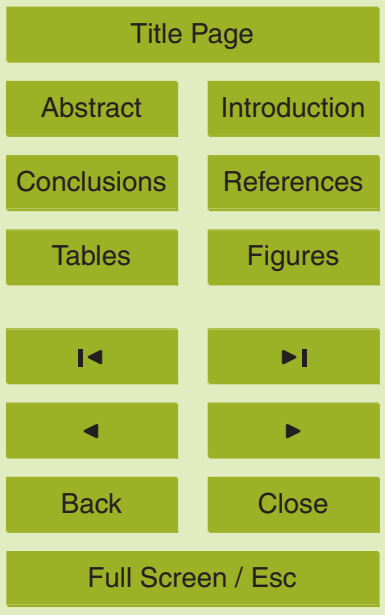

Printer-friendly Version

Interactive Discussion 
BGD

8, 831-856, 2011

\section{$\delta^{13} \mathrm{C}$ as a proxy of phytoplankton community structure change}

Table 1. Basic hydrochemical parameters of the reservoirs.

\begin{tabular}{lccc}
\hline & Along Maotiao River & Along Sancha River & Along main Wujiang River \\
\hline Temperature $\left({ }^{\circ} \mathrm{C}\right)$ & $19.0 \pm 4.6^{\mathrm{a}}(11.1-26.4)^{\mathrm{b}}$ & $18.6 \pm 5.3(9.7-28.9)$ & $18.0 \pm 5.0(10.9-30.0)$ \\
$\mathrm{pH}$ & $8.3 \pm 0.6(7.6-9.4)$ & $8.2 \pm 0.3(7.7-8.7)$ & $8.1 \pm 0.5(7.4-9.3)$ \\
$\mathrm{DO}\left(\mathrm{mg} \mathrm{L}^{-1}\right)$ & $8.0 \pm 3.4(3.4-15.0)$ & $9.0 \pm 0.9(7.4-10.5)$ & $8.8 \pm 2.4(5.0-18.1)$ \\
$\mathrm{Ca}^{2+}\left(\mathrm{mg} \mathrm{L}^{-1}\right)$ & $54.9 \pm 7.1(35.5-63.9)$ & $61.1 \pm 8.8(45.0-75.9)$ & $57.6 \pm 4.9(43.4-63.2)$ \\
$\mathrm{Mg}^{2+}\left(\mathrm{mg} \mathrm{L}^{-1}\right)$ & $14.7 \pm 0.9(11.9-16.2)$ & $9.6 \pm 1.7(6.0-12.0)$ & $9.8 \pm 1.2(6.9-12.0)$ \\
$\mathrm{HCO}_{3}^{-}\left(\mathrm{mg} \mathrm{L}^{-1}\right)$ & $139.1 \pm 27.5(82.4-180.9)$ & $152.9 \pm 12.3(135.3-182.9)$ & $141.4 \pm 12.2(105.8-181.3)$ \\
$\mathrm{SO}_{4}^{2-}\left(\mathrm{mg} \mathrm{L}^{-1}\right)$ & $102.3 \pm 19.3(56.8-133.9)$ & $105.5 \pm 23.8(72.1-151.6)$ & $80.4 \pm 8.2(59.8-94.0)$ \\
\hline
\end{tabular}

${ }^{\text {a }}$ Average \pm SD.

${ }^{\mathrm{b}}$ Min-Max. DO, dissolved oxygen.
B. Wang et al.

Title Page

Abstract

Introduction

Conclusions

References

Tables

Figures

14

$>1$

4

Back

Close

Full Screen / Esc

Printer-friendly Version

Interactive Discussion 
Table 2. Compositions of phytoplankton community structure from the reservoirs.

\begin{tabular}{|c|c|c|c|c|c|c|c|c|c|}
\hline Site & Bacillariophyta & $\begin{array}{l}\text { Chlorophyta } \\
\mathrm{mg} \mathrm{L}^{-1} \text { (wet w }\end{array}$ & $\begin{array}{l}\text { Cyanophyta } \\
\text { weight) }\end{array}$ & Dinophyta & Site & Bacillariophyta & $\begin{array}{l}\text { Chlorophyta } \\
\mathrm{mg} \mathrm{L}^{-1} \text { (wet }\end{array}$ & $\begin{array}{l}\text { Cyanophyta } \\
\text { weight) }\end{array}$ & Dinophyta \\
\hline \multicolumn{5}{|c|}{ July 2007} & \multicolumn{5}{|c|}{ January 2008} \\
\hline M1 & 0.86 & 9.68 & 24.68 & 0.00 & M1 & 1.58 & 13.33 & 0.12 & 0.00 \\
\hline M2 & 0.44 & 3.65 & 2.54 & 4.40 & M2 & 1.87 & 1.69 & 0.09 & 0.55 \\
\hline M3 & 0.26 & 1.80 & 0.06 & 3.30 & M3 & 3.50 & 0.68 & 0.00 & 0.00 \\
\hline M4 & 0.15 & 3.67 & 0.00 & 0.03 & M4 & 5.46 & 0.57 & 0.04 & 0.00 \\
\hline M5 & 1.76 & 23.98 & 0.27 & 27.50 & M5 & - & - & - & - \\
\hline S1 & 3.60 & 7.39 & 0.01 & 0.12 & $\mathrm{~S} 1$ & 14.78 & 0.35 & 0.00 & 0.00 \\
\hline S2 & 0.59 & 1.34 & 0.00 & 0.03 & S2 & 5.76 & 0.00 & 0.02 & 0.00 \\
\hline S3 & 1.89 & 5.15 & 0.04 & 2.20 & S3 & 3.17 & 0.26 & 0.00 & 0.00 \\
\hline S4 & 0.78 & 2.11 & 0.00 & 0.02 & S4 & 1.28 & 0.44 & 0.01 & 0.00 \\
\hline W1 & 0.87 & 4.09 & 0.00 & 0.00 & W1 & 0.62 & 0.62 & 0.00 & 0.00 \\
\hline W2 & 0.30 & 2.64 & 0.00 & 0.00 & W2 & 0.70 & 0.70 & 0.00 & 0.00 \\
\hline W3 & 5.51 & 2.42 & 0.00 & 0.12 & W3 & 0.48 & 0.88 & 0.00 & 0.00 \\
\hline W4 & 1.49 & 0.84 & 0.00 & 0.05 & W4 & 0.53 & 0.70 & 0.00 & 0.00 \\
\hline W5 & 0.63 & 2.71 & 0.00 & 1.65 & W5 & 0.44 & 1.80 & 0.00 & 0.00 \\
\hline W6 & 0.42 & 2.64 & 0.00 & 1.65 & W6 & 0.92 & 1.67 & 0.00 & 0.00 \\
\hline W7 & 0.30 & 6.16 & 0.00 & 2.75 & W7 & 1.65 & 1.14 & 0.01 & 0.00 \\
\hline W8 & 1.27 & 18.79 & 0.01 & 15.40 & W8 & 3.12 & 0.48 & 0.00 & 0.00 \\
\hline W9 & 1.30 & 34.54 & 0.16 & 12.10 & W9 & 0.44 & 4.14 & 0.00 & 0.00 \\
\hline W10 & 0.68 & 2.95 & 0.03 & 0.55 & W10 & 0.97 & 1.06 & 0.00 & 0.00 \\
\hline \multicolumn{5}{|c|}{ October 2007} & \multicolumn{5}{|c|}{ April 2008} \\
\hline M1 & 0.66 & 6.60 & 0.74 & 0.28 & M1 & 0.48 & 49.72 & 0.05 & 0.00 \\
\hline M2 & 3.28 & 4.03 & 7.55 & 0.22 & M2 & 0.75 & 2.90 & 0.11 & 0.00 \\
\hline M3 & 2.84 & 1.47 & 0.18 & 0.10 & M3 & 0.97 & 2.29 & 0.01 & 0.00 \\
\hline M4 & 2.68 & 2.75 & 0.03 & 0.10 & M4 & 0.31 & 0.84 & 0.00 & 0.00 \\
\hline M5 & 4.53 & 2.46 & 0.02 & 0.30 & M5 & 1.28 & 1.96 & 0.01 & 0.00 \\
\hline S1 & 1.80 & 2.79 & 0.00 & 0.05 & $\mathrm{~S} 1$ & 3.54 & 0.33 & 0.00 & 0.00 \\
\hline S2 & 1.08 & 1.54 & 0.00 & 0.01 & S2 & 3.01 & 0.40 & 0.00 & 0.00 \\
\hline S3 & 2.22 & 2.02 & 0.00 & 0.02 & S3 & 10.56 & 0.31 & 0.00 & 0.00 \\
\hline S4 & 1.06 & 2.02 & 0.00 & 0.00 & S4 & 9.11 & 0.40 & 0.00 & 0.00 \\
\hline W1 & 3.67 & 7.81 & 0.24 & 0.03 & W1 & 1.74 & 0.90 & 0.00 & 0.01 \\
\hline W2 & 0.13 & 0.97 & 0.00 & 0.00 & W2 & 0.88 & 0.26 & 0.00 & 0.00 \\
\hline W3 & 3.78 & 1.65 & 0.05 & 0.00 & W3 & 1.30 & 1.83 & 0.00 & 0.02 \\
\hline W4 & 2.71 & 0.86 & 0.03 & 0.00 & W4 & 1.50 & 0.88 & 0.00 & 0.00 \\
\hline W5 & 2.51 & 2.20 & 0.06 & 0.00 & W5 & 1.94 & 0.59 & 0.00 & 0.00 \\
\hline W6 & 1.56 & 1.47 & 0.00 & 0.00 & W6 & 1.72 & 1.48 & 0.00 & 0.00 \\
\hline W7 & 1.52 & 2.38 & 0.01 & 0.02 & W7 & 2.24 & 0.84 & 0.00 & 0.02 \\
\hline W8 & 1.74 & 1.30 & 0.19 & 0.55 & W8 & 8.93 & 0.18 & 0.00 & 0.00 \\
\hline W9 & 0.84 & 0.81 & 0.19 & 0.14 & W9 & 12.91 & 1.67 & 0.00 & 0.00 \\
\hline W10 & 0.62 & 0.51 & 0.08 & 0.05 & W10 & 2.95 & 0.09 & 0.00 & 0.00 \\
\hline
\end{tabular}

- Stands for not detected.
BGD

8, 831-856, 2011

\section{$\delta^{13} \mathrm{C}$ as a proxy of phytoplankton \\ community structure change}

B. Wang et al.

\section{Title Page}

\section{Abstract}

Introduction

Conclusions

References

Tables

Figures

14

Back

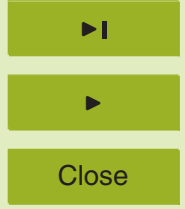

Full Screen / Esc

Printer-friendly Version

Interactive Discussion 
Table 3. Values of $\delta^{13} \mathrm{C}_{\mathrm{DIC}}, \delta^{13} \mathrm{C}_{\mathrm{POC}}$, and $\delta^{13} \mathrm{C}_{\mathrm{PPC}}(\%)$ from the reservoirs.

\section{BGD}

\begin{tabular}{|c|c|c|c|c|c|c|c|}
\hline Site & $\delta^{13} \mathrm{C}_{\mathrm{DIC}}$ & $\delta^{13} \mathrm{C}_{\mathrm{POC}}$ & $\delta^{13} \mathrm{C}_{\mathrm{PPC}}$ & Site & $\delta^{13} \mathrm{C}_{\mathrm{DIC}}$ & $\delta^{13} \mathrm{C}_{\mathrm{POC}}$ & $\delta^{13} \mathrm{C}_{\mathrm{PPC}}$ \\
\hline \multicolumn{4}{|c|}{ July 2007} & \multicolumn{4}{|c|}{ January 2008} \\
\hline M1 & -5.1 & -22.1 & -24.9 & M1 & -6.3 & -31.0 & -33.1 \\
\hline M2 & -7.1 & -24.2 & -22.9 & M2 & -9.4 & -33.8 & -39.2 \\
\hline M3 & -8.5 & -26.3 & -24.1 & M3 & -8.8 & -34.5 & -38.2 \\
\hline M4 & -9.0 & -27.2 & - & M4 & -8.0 & -31.6 & - \\
\hline M5 & -6.7 & -20.8 & -18.6 & M5 & - & - & - \\
\hline S1 & -6.4 & -29.5 & -28.0 & S1 & -7.5 & -32.8 & -38.1 \\
\hline S2 & -9.6 & -28.3 & -31.2 & S2 & -7.7 & -30.3 & -33.8 \\
\hline S3 & -7.7 & -28.9 & -28.1 & S3 & -8.5 & -31.3 & -38.0 \\
\hline S4 & -9.3 & -29.2 & -30.7 & S4 & -8.4 & -30.4 & -28.9 \\
\hline W1 & -4.5 & -32.3 & - & W1 & -8.9 & -31.1 & -33.8 \\
\hline W2 & -8.8 & -28.4 & - & W2 & -9.0 & -30.9 & -31.0 \\
\hline W3 & -6.5 & -27.4 & -26.3 & W3 & -8.9 & -31.6 & -31.5 \\
\hline W4 & -9.1 & -29.3 & - & W4 & -9.1 & -31.6 & -30.9 \\
\hline W5 & -8.6 & -26.0 & -26.0 & W5 & -8.8 & -30.6 & -29.9 \\
\hline W6 & -9.2 & -29.2 & - & W6 & -8.7 & -30.2 & - \\
\hline W7 & -7.6 & -30.9 & -25.7 & W7 & -8.6 & -29.7 & -33.9 \\
\hline W8 & -5.5 & -19.6 & - & W8 & -8.9 & -29.5 & -33.9 \\
\hline W9 & -7.3 & -22.3 & -24.3 & W9 & -9.0 & -30.9 & -32.6 \\
\hline W10 & -9.4 & -26.0 & -24.1 & W10 & -9.0 & -29.5 & -31.9 \\
\hline \multicolumn{4}{|c|}{ October 2007} & \multicolumn{4}{|c|}{ April 2008} \\
\hline M1 & -8.0 & -29.1 & -28.3 & M1 & -3.3 & -24.0 & -15.1 \\
\hline M2 & -9.3 & -31.0 & -33.1 & M2 & -5.4 & -26.1 & -26.7 \\
\hline M3 & -9.6 & -30.2 & -30.0 & M3 & -7.4 & -29.4 & -30.2 \\
\hline M4 & -9.4 & -29.3 & - & M4 & -7.6 & -29.1 & - \\
\hline M5 & -9.2 & -32.1 & -33.2 & M5 & -5.7 & -32.1 & -33.6 \\
\hline $\mathrm{S} 1$ & -8.0 & -31.3 & -33.0 & $\mathrm{~S} 1$ & -6.2 & - & -31.5 \\
\hline S2 & -8.9 & -30.9 & -32.5 & $\mathrm{~S} 2$ & -7.2 & -29.3 & -35.6 \\
\hline S3 & -8.5 & -32.4 & -29.6 & S3 & -6.8 & -30.2 & -29.6 \\
\hline S4 & -8.7 & -30.3 & -29.4 & S4 & -7.5 & -31.0 & -36.3 \\
\hline W1 & -8.1 & -32.1 & - & W1 & -7.8 & -30.5 & -35.2 \\
\hline W2 & -9.5 & -29.7 & - & W2 & -9.5 & -30.8 & -34.1 \\
\hline W3 & -8.5 & -30.2 & -33.1 & W3 & -7.4 & -32.8 & -35.5 \\
\hline W4 & -8.9 & -29.3 & -30.6 & W4 & -8.6 & -30.2 & -30.8 \\
\hline W5 & -9.2 & -30.5 & -32.6 & W5 & -8.2 & -31.6 & -34.8 \\
\hline W6 & -8.9 & -30.2 & -31.1 & W6 & -8.6 & -30.4 & -33.5 \\
\hline W7 & -9.0 & -30.3 & -29.8 & W7 & -7.9 & -32.3 & -37.6 \\
\hline W8 & -9.5 & -27.1 & -30.2 & W8 & -6.6 & -31.9 & -33.6 \\
\hline W9 & -10.0 & -31.9 & -30.7 & W9 & -6.9 & -30.1 & -31.7 \\
\hline W10 & -9.7 & -31.0 & -30.2 & W10 & -8.6 & -30.5 & -32.0 \\
\hline
\end{tabular}

8, 831-856, 2011

\section{$\delta^{13} \mathrm{C}$ as a proxy of phytoplankton \\ community structure change}

B. Wang et al.

Title Page

Abstract

Conclusions

Tables

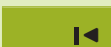

14

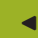

Back

Full Screen / Esc

Printer-friendly Version

Interactive Discussion 


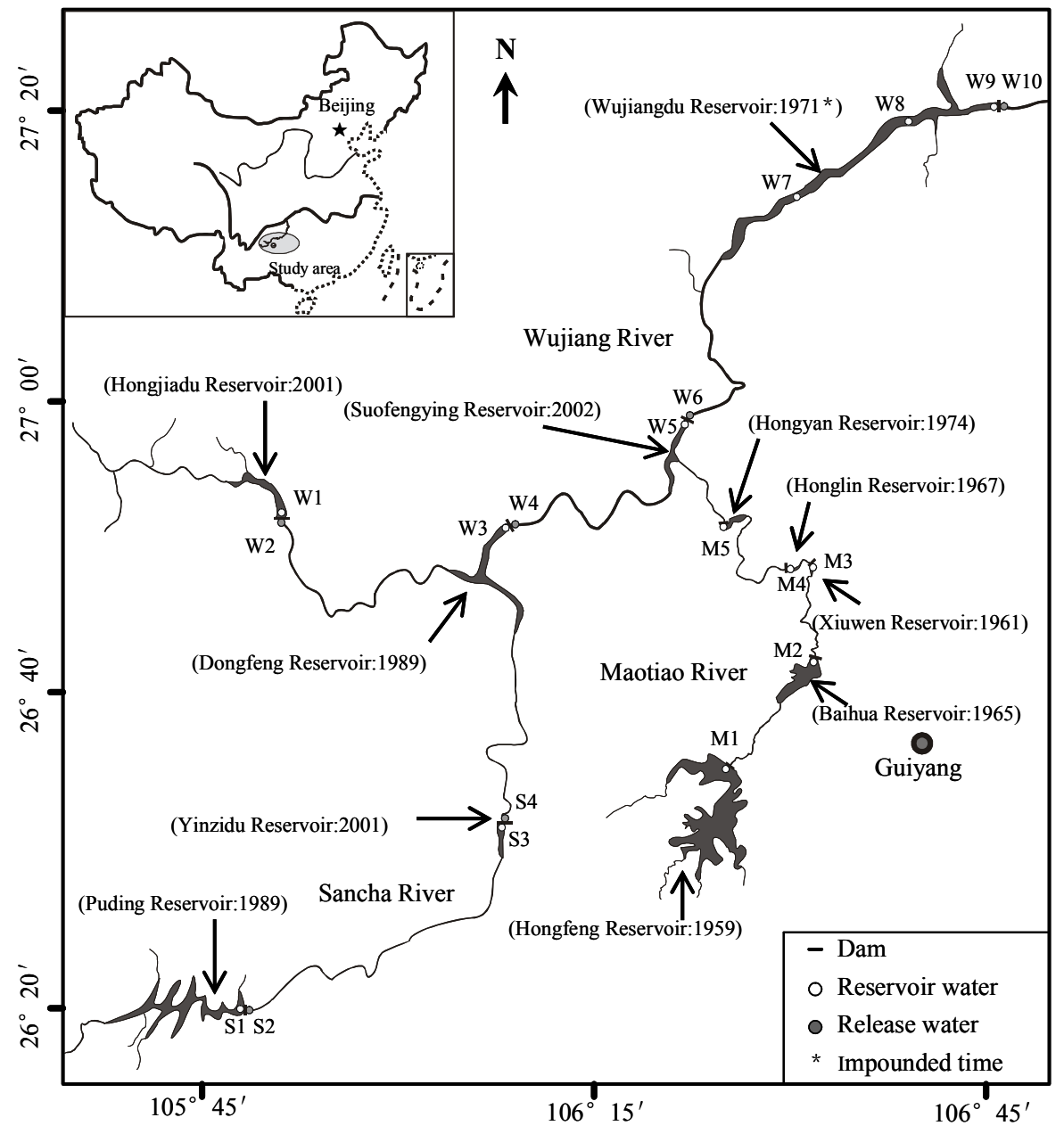

BGD

8, 831-856, 2011

\section{$\delta^{13} \mathrm{C}$ as a proxy of phytoplankton community structure change}

B. Wang et al.

\section{Title Page}

\section{Abstract}

Introduction

Conclusions

References

Tables

Figures

14

4

Back

Close

\section{Full Screen / Esc}

Printer-friendly Version

Interactive Discussion

Fig. 1. Map showing sampling locations and sample numbers. 


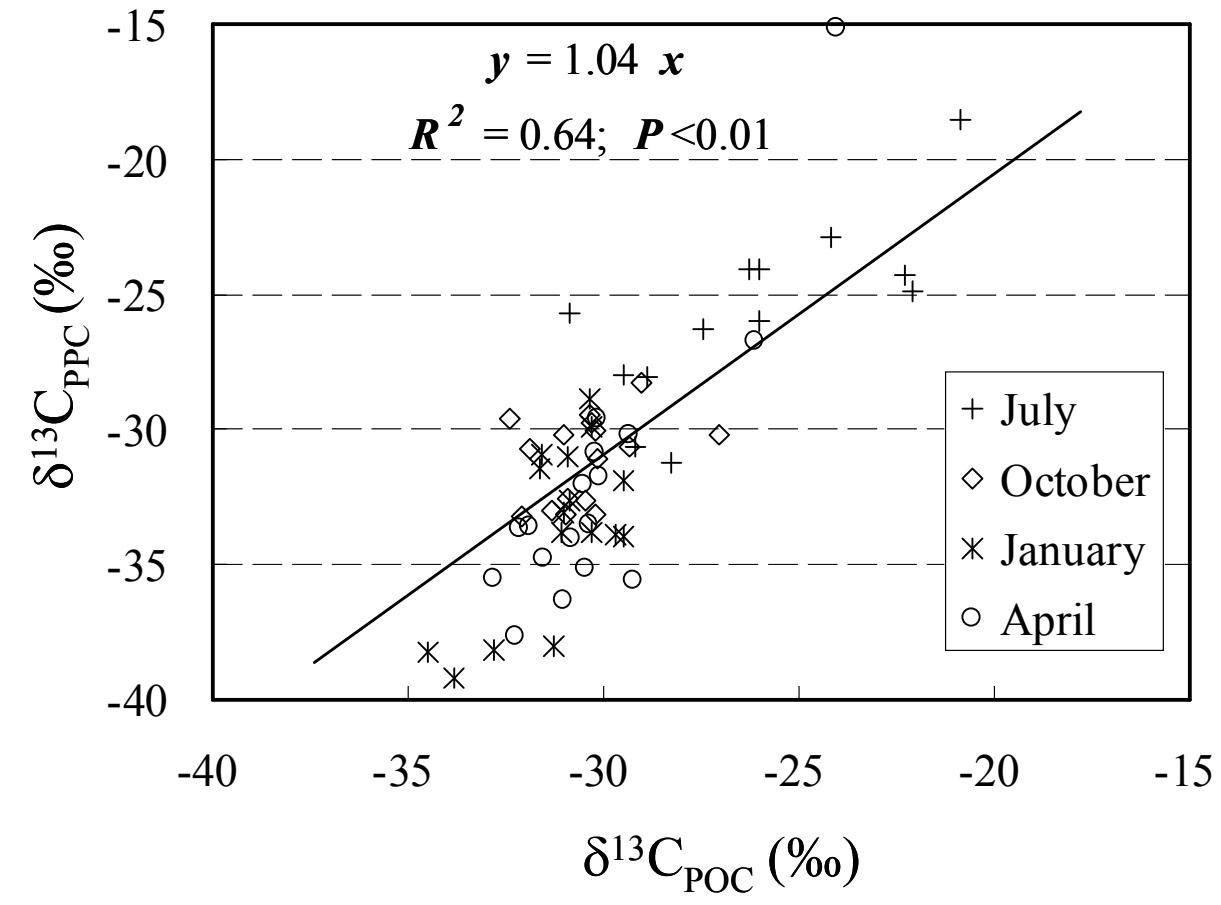

\section{BGD}

8, 831-856, 2011

\section{$\delta^{13} \mathrm{C}$ as a proxy of} phytoplankton community structure change

B. Wang et al.

Title Page

Abstract

Introduction

Conclusions

Tables

References

Figures

14

4

Back

Full Screen / Esc

Printer-friendly Version

Interactive Discussion 
BGD

8, 831-856, 2011

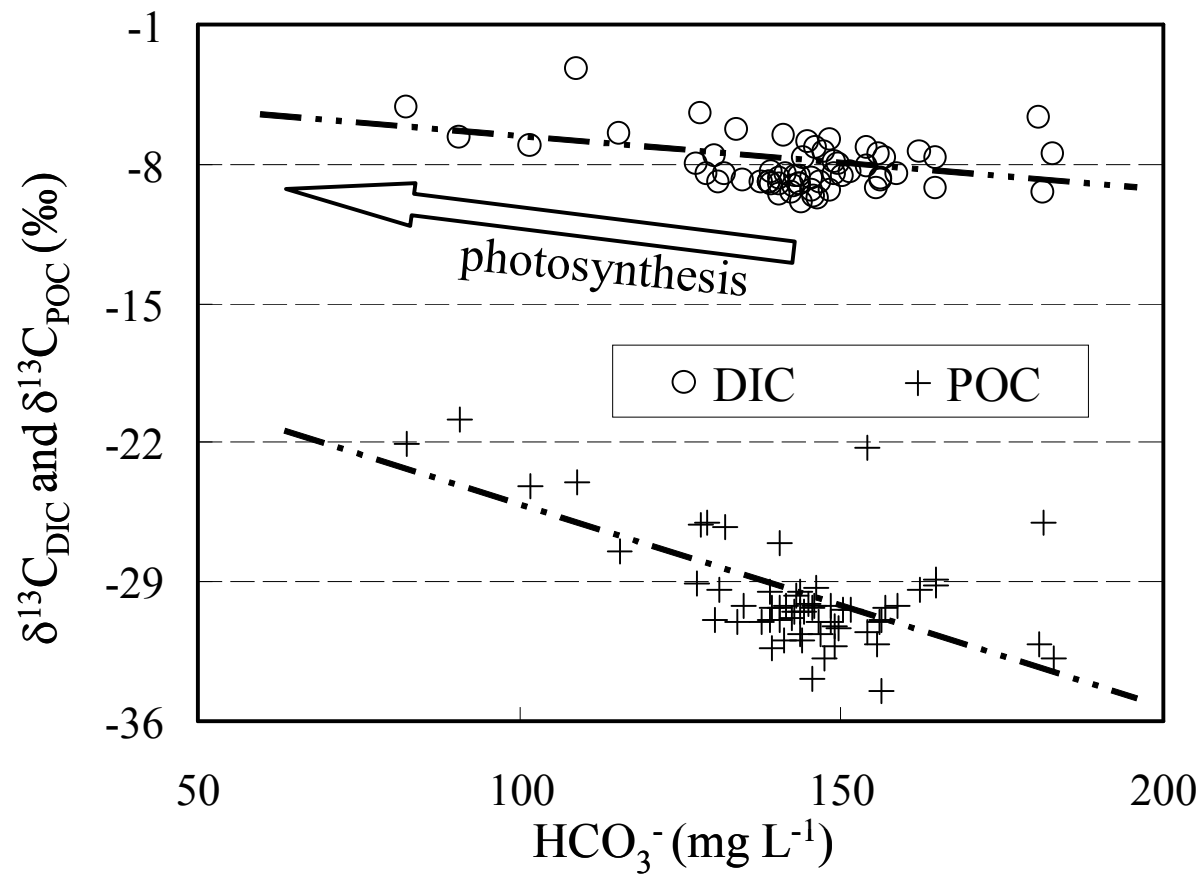

Fig. 3. Concentration of $\mathrm{HCO}_{3}^{-}$vs. $\delta^{13} \mathrm{C}_{\mathrm{DIC}}$ and $\delta^{13} \mathrm{C}_{\mathrm{POC}}$, respectively. $\delta^{13} \mathrm{C}$ as a proxy of community structure change

B. Wang et al.

Title Page

Abstract

Introduction

Conclusions

References

Tables

Figures

14

$>$ I

$\triangleleft$

Back

Close

Printer-friendly Version

Interactive Discussion phytoplankton

Full Screen / Esc 
BGD

8, 831-856, 2011

\section{$\delta^{13} \mathrm{C}$ as a proxy of phytoplankton \\ community structure change}

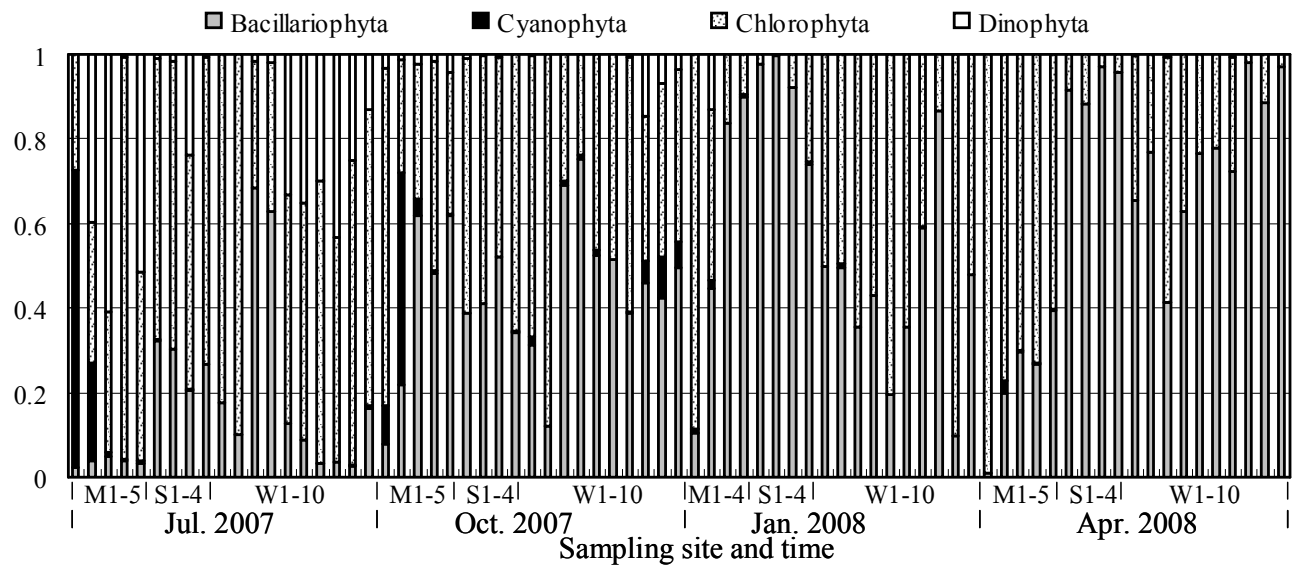

B. Wang et al.

Title Page

Abstract

Introduction

Conclusions

References

Tables

Figures

14

- I

4

Back

Close

Full Screen / Esc

Printer-friendly Version

Interactive Discussion 


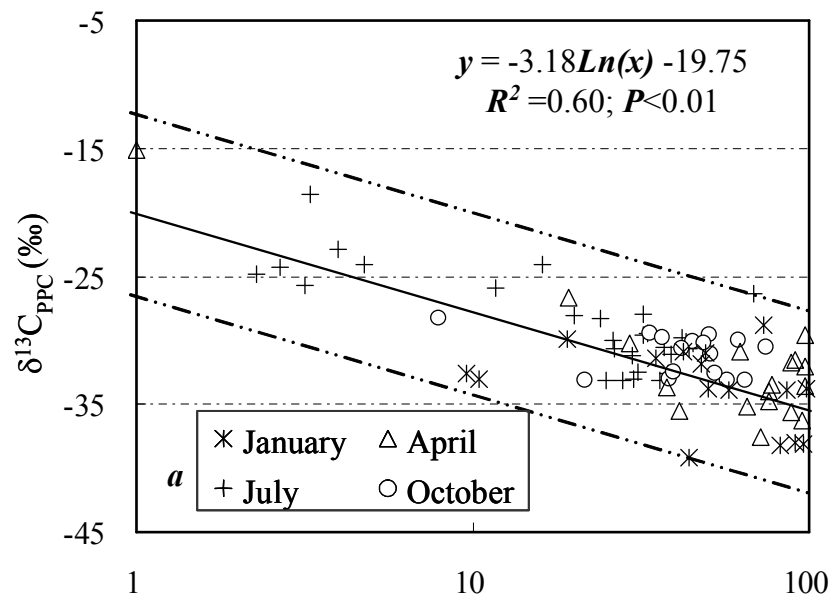

\section{BGD}

8, 831-856, 2011

\section{$\delta^{13} \mathrm{C}$ as a proxy of phytoplankton community structure change}

B. Wang et al.

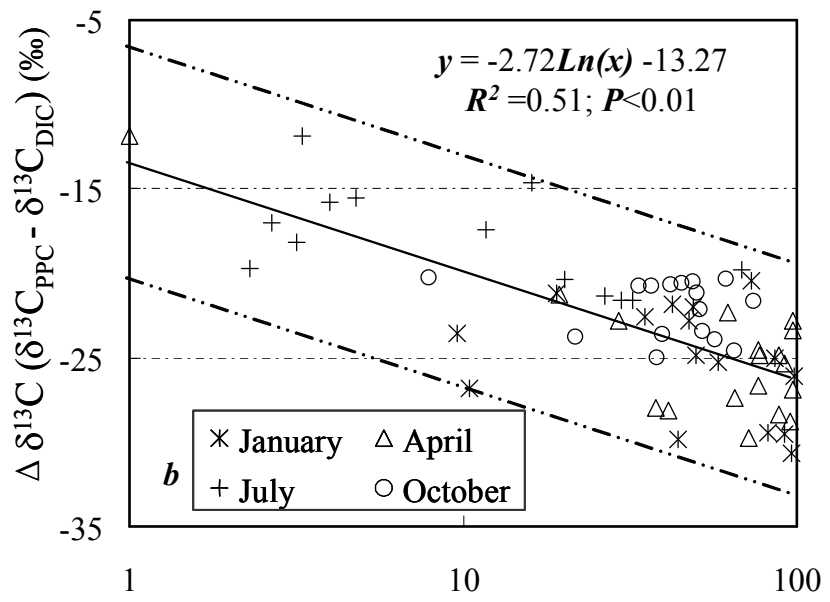

Title Page

Abstract Introduction

Conclusions

References

Tables

Figures

14

$\rightarrow$ I

4

Back

Close

\section{Full Screen / Esc}

Printer-friendly Version

Interactive Discussion

Fig. 5. Contribution of Bacillariophyta to the total phytoplankton vs. $\delta^{13} \mathrm{C}_{\mathrm{PPC}}$ and $\Delta \delta^{13} \mathrm{C}$ $\left(\delta^{13} \mathrm{C}_{\mathrm{PPC}}-\delta^{13} \mathrm{C}_{\mathrm{DIC}}\right)$, respectively. 


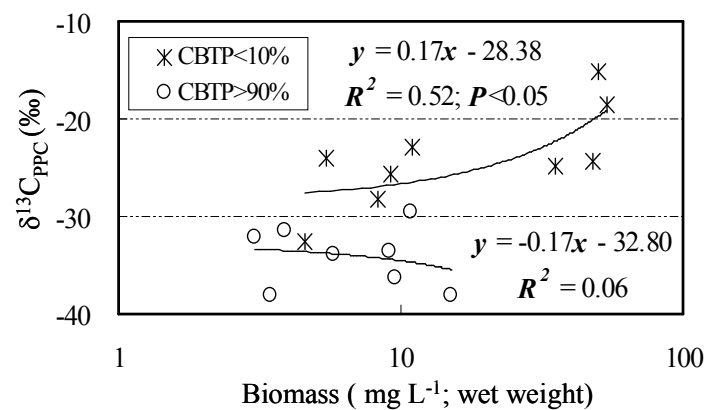

\section{BGD}

8, 831-856, 2011

\section{$\delta^{13} \mathrm{C}$ as a proxy of phytoplankton community structure change}
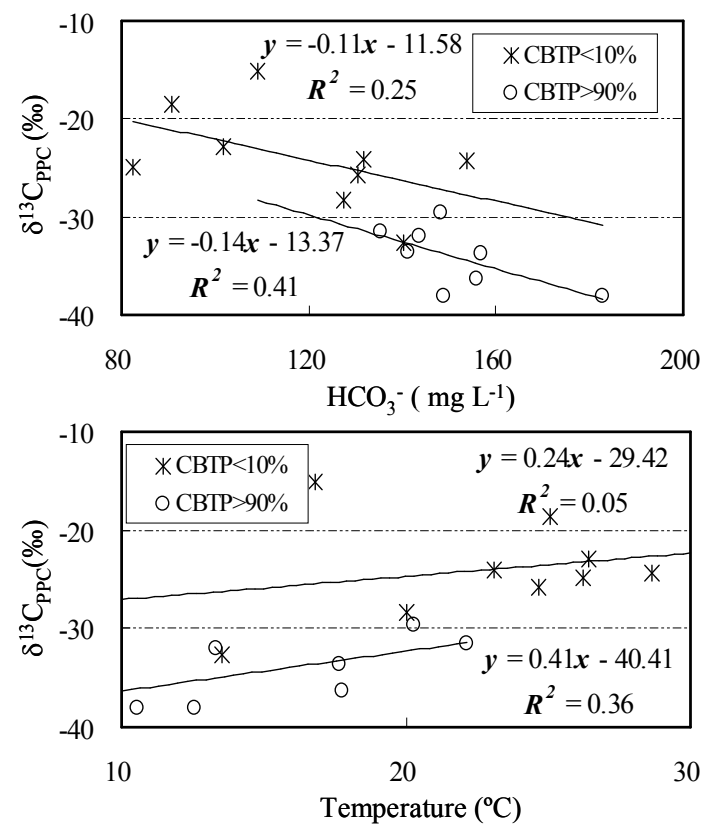

B. Wang et al.

Title Page

Abstract Introduction

Conclusions

References

Tables

Figures

14

4

Back

Close

\section{Full Screen / Esc}

Printer-friendly Version

Interactive Discussion

Fig. 6. $\delta^{13} \mathrm{C}_{\mathrm{PPC}}$ vs. biomass of phytoplankton, $\mathrm{HCO}_{3}^{-}$, and temperature, respectively, at CBTP $>90 \%$ and $<10 \%$ conditions. 